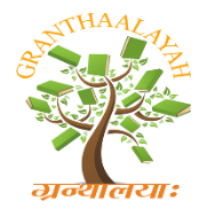
INTERNATIONAL JOURNAL OF RESEARCH
GRANTHAALAYAH
A knowledge Repository

Science

\title{
HYPERTENSIVE DISORDERS IN ECUADORIAN PREGNANT WOMEN 2010-2014
}

\author{
Dr. Jorge Daher Nader, Msc ${ }^{1}$, Msc Alida Bella Vallejo López ${ }^{2}$ \\ *1,2 Teacher of the Faculty of Medical Sciences, University of Guayaquil, Ecuador
}

\begin{abstract}
Hypertensive disorders are serious illnesses that manifest in different forms and can be fatal. This study aims to demonstrate the impact of hypertensive disorders in pregnancy and the difficulty in public health by limiting timely identification and diagnosis of these diseases. The completion of this study will help to obtain the information necessary to understand the manifestations of hypertensive disorders in the Maternity Enrique C. Sotomayor on a study period of 5 years. The study will be beneficial for the pregnant patient and the institution as valuable information is obtained to analyze the behavior of these disorders and to perform protocol of information for professionals in the institution.

Among the results obtained during five years in the institution were 13.066 patients diagnosed with hypertensive disorders, severe preeclampsia being the most common hypertensive stage with $77.3 \%$. There is a significant increase of the disease with the passing of the years, and in 2013 was the second cause of c-sections for the first time in patients with seven antenatal control program. Death by hypertension in pregnancy was presented in three occasions. With regard to the damages in the fetus birth weight is frequently altered, reporting in 2014-571 newborns diagnosed with growth retardation and fetal malnutrition.
\end{abstract}

Keywords: Hypertensive Disorders Pregnancy; Preeclampsia.

Cite This Article: Dr. Jorge Daher Nader, and Alida Bella Vallejo López. (2018). "HYPERTENSIVE DISORDERS IN ECUADORIAN PREGNANT WOMEN 2010-2014." International Journal of Research - Granthaalayah, 6(8), 238-247. https://doi.org/10.29121/granthaalayah.v6.i8.2018.1456.

\section{Introduction}

Hypertension in pregnancy is a disease that brings high morbidity to the mother-child binomial. It can also be fatal by causing coagulation disorders and irreversible situations such as hepatic rupture or cerebrovascular accident. Hypertension is recognized when the blood pressure values in the pregnant woman are above or equal to $140 / 100 \mathrm{mmHg}$. There are different variants of involvement in the pregnant woman and its classification depends on the presence or not of other factors such as proteinuria, being a sign of alarm when presenting blood pressure above normal values, and are categorized as pregnant women with pre-eclampsia, presenting This disease, 
approximately $10 \%$, can reach its most severe manifestation of Eclampsia, in which tonic-clonic seizures can cause maternal-fetal mortality. Both Preeclampsia and Eclampsia are multisystem disorders, with serious alterations in the renal, cardiovascular and central nervous system. In international literature, the association between pregnant women with gestational hypertension (whether or not they have proteinuria) and the presence of alteration in the endovascular trophoblastic invasion was published. This alteration in the invasiveness causes the inadequate development of the vascular endothelium compromising the uterine-placental flow $(1,2)$. At the moment there is a ratio of 45.9 maternal deaths per 100 thousand live births. In 2012, 205 were registered, the following year 155 and in 2014 there are 72, but this number may decrease, since it would not be a direct result of maternity. $76 \%$ of deaths occur in mixed ethnic groups and $22 \%$ among ethnic groups of indigenous peoples (10). The risk factors described to date are: the extreme ages of the woman's reproductive life, low level of education at school, nulliparity, family history of pre-eclampsia-eclampsia, obesity. (8)

A systematic analysis of the World Health Organization (WHO) on the causes of maternal mortality has shown that hypertensive children are one of the main causes of maternal death in developing countries, with countries such as Africa being more vulnerable., Latin America and the Caribbean. (9) The incidence of eclampsia in the components of a country and Europe is similar and is estimated at 5 to 7 cases per 10,000 parts, while in developing countries it is variable, ranging from 1 case per 100 pregnancies to 1 per every 1,700 pregnancies (13). Rates for African countries such as South Africa, Egypt and Ethiopia vary from 1.8\% to 7.1\% and in Nigeria, the prevalence ranges from $2 \%$ to $16.7 \%$ (12).

Colombia reflects more than 300 deaths per year. This is what happened in Latin America and the Caribbean. What Profamilia did in 2010 and which places a country in fourth place in Latin America with the highest number of cases due to this phenomenon. (7)

Hypertensive disorders manifest after the twentieth week of gestation, during delivery or in the first six weeks after it, with a clinical picture characterized by hypertension equal to or greater than $140 / 90 \mathrm{mmHg}$ with or without proteinuria, edema itself which is considered a frequent but not main sign, headache, tinnitus, epigastralgia and alterations in laboratory tests. $(1,11)$. The objective of the research is to describe the main complications that occur in pregnant women with hypertensive disorders.

This stage became a serious public health problem that no longer knows its etiology and therefore it is difficult to prevent manifestations and irreversible complications for the mother and the fetus. In general, this proteinuria is not detected until after 20 weeks of gestation and it is estimated that $7 \%$ of births are affected by these hypertensive states (4), and reports that approximately 75,000 maternal deaths occur worldwide. Every year (3)

The most serious alterations that occur in these hypertensive disorders are generalized vasospasm that affects several organs $(4,5)$.

If there are neurological symptoms or clonic tonic seizures, it becomes Eclampsia, which can cause irreversible damage to the central nervous system, or coagulation disorders can also occur, termed HELLP syndrome, which is highly fatal. The hypertensive gestational disorders are one of the 
significant causes of maternal mortality and produce considerable perinatal morbidity and mortality. The perinatal mortality rate is higher in neonates of women complicated with hypertensive disorders. This disease is associated with fetal intrauterine growth restriction and a premature newborn (6). Several research works in the whole world and in hospital and academic institutions on gestational hypertensive disorders, on the etiological causes of these pathologies that cause complications in the health of patients in many developing countries like Ecuador. Currently, certain hypotheses show that hypertension causes damage to the level of the endothelial vessels affecting the body, which causes widespread systemic disease. Among them the hypothesis or genetic theory which states that these conditions have a direct relationship with family predisposition, increasing the incidence in the sisters and daughters of pre-eclamptic and eclamptic, It is assumed the coexistence of a gene in chromosomes 1, 3, 9, or 18 directly involved in this pathology.

\section{Chronic Blood Hypertension}

It is a high risk factor because many studies show that the hypertensive disease of pregnancy is added to pre-existing hypertension. Chronic arterial hypertension produces vascular injury by various mechanisms, which can determine an inadequate oxygenation of the trophoblast and favors the emergence of hypertensive disorders of pregnancy In obesity, adipocytes secrete tumor necrosis factor (TNFa), which causes vascular injury and aggravates oxidative stress There is an increase in oxidative stress and endothelial damage, all of which can affect utero-placental perfusion and favor the emergence of pre-eclampsia.

Pathologies such as diabetes mellitus (diabetic nephropathy) and arterial hypertension (nephroangiosclerosis) favor the development of pre-eclampsia.

\section{Maternal and Fetal Complications}

Women with severe pre-eclampsia are susceptible to severe complications such as pulmonary edema, respiratory failure, premature Placental Normoinserta (DPPNI) detachment, disseminated intravascular coagulation (DIC), hepatic or renal failure, hematomas or hepatic rupture, cerebrovascular disease (CVA), Cortical Blindness, Retinal Detachment, Convulsive Eclamptic Crises and Multiple Organ Failure.

The risks associated with seizures are severe hypoxia due to recurrence, maternal trauma and aspiration pneumonia.

\section{Material and Method}

The research work was carried out in the Hospital E. C. Sotomayor of specialty gynecology and obstetrics and sexual and reproductive health care in Ecuador of the Charity Board of Guayaquil, non-profit non-governmental organization. The design of the study is descriptive, cross-sectional and retrospective from January 1, 2010 to December 31, 2014 with diagnosis of hypertension. The universe of study research work was selected through the clinical records of patients who had gestational hypertensive disease, admitted to the hospital E. C. Sotomayor, which during the quinquennium 2010-2014 is 13,066 (Table1) 
Table 1: Patients Hypertensive Disease Gestacional Quinquenio 2010-2014

\begin{tabular}{|l|l|}
\hline YEARS & PATIENTS \\
\hline 2010 & 2264 \\
\hline 2011 & 2522 \\
\hline 2012 & 2822 \\
\hline 2013 & 2594 \\
\hline 2014 & 2864 \\
\hline TOTAL & $\mathbf{1 3 0 6 6}$ \\
\hline
\end{tabular}

Sample: The sample consists of pregnant women with hypertensive disorders treated in the aforementioned Hospital; The information of the patients was collected in a data sheet prepared with the information obtained from the database of the hospital statistics department. It is important to emphasize that to establish the probabilistic sample, through random selection of patients with gestational hypertensive disease, the netquest.com source was used, which has high confidence, decreases biases and increases the reliability of the investigated data.

It is a descriptive research, not experimental, transversal and retrospective.

Statistical analysis and interpretation of information.

With the data collected from the clinical records of the five years included in the study, a database will be formed in which the following variables will be detailed: the hypertensive state presented by the pregnant woman and the frequency of cases, the type of maternal-fetal complication occurred, if cesarean section was applied or not for delivery and if the hypertensive complications ended in maternal and / or neonatal death. The base information was exported for analysis, for which the "Statistical Package for the Social Sciences" SPSS package will be used in its version 22 . The values that present levels of significance of $5 \%(\mathrm{p} \leq 0.05)$ will be considered statistically significant.

\section{Research Ethics}

Within the study, all national and international ethical agreements will be respected, avoiding exposing the privacy of patients in the medical records. Only maternal data will be included excluding access to information on name, place of residence, or any data that may affect and harm the integrity of patients.

\section{Results}

During a study period of 4 years in the institution, there were 13,066 patients with diagnosed hypertensive disorders, with severe pre-eclampsia being the hypertensive stage with the highest prevalence, representing $77.3 \%$ (Table 2) of the total cases. Similarly, during the study period, severe pre-eclampsia constitutes $88 \%$ of cases of hypertensive disorders in pregnancy in 2014, within which a significant and progressive rise can be observed during the years evaluated: 2010 $62.8 \%, 201168.7 \%, 201286 \%$ and in $201386.9 \%$, respectively, while moderate pre-eclampsia, its epidemiological behavior is contrary, decreasing annually. 
Within the analysis regarding the residence site within the sample studied, it was determined that a high percentage of pregnant women with pre-eclampsia live in rural areas (42\%). According to the personal pathological history as a predisposing factor for pre-eclampsia in the investigation, it is observed that a great majority of pregnant women with hypertensive disorders did not present pathological antecedents (94\%). It was observed that pregnant women with hypertensive disorders had full-term newborns in their majority (69\%). When evaluating maternal-fetal complications due to hypertensive disorders, it was observed that the most frequent fetal-neonatal complication was neonatal depression and there was low fetal death. It was possible to observe the majority of pregnant women who presented hypertensive disorders had minimal prenatal controls (less than 5 prenatal controls) and a low percentage did not present any control.

\section{Discussion}

Magel V (2014) in her study that sought to identify the risk factors associated with pre-eclampsia, found that the factors associated with pre-eclampsia were maternal age $>35$ years, nulliparity and family history of mother with pre-eclampsia or sister, for which early prenatal care is necessary to ensure early diagnosis and timely management of this entity. Bilano VL. (2014) in their study to identify the risk factors associated with pre-eclampsia / eclampsia found that maternality $\geq 30$ and a low educational level and within the clinical and obstetric variables, nulliparity, absence of prenatal care, Chronic hypertension was significantly associated with an increased risk of preeclampsia / eclampsia. The study determined that the majority of the patients who presented hypertensive disorders were more than 37 years old in relation to those shown by Magel V. and Bilano VL (2014) considering that the age greater than 35 years is one of the risk factors that predisposes Hypertensive disorders.

Bigelow CA. (2014) in their study found that among the different risk factors associated with the occurrence of late postpartum pre-eclampsia in women who had no history was associated with factors such as age $\geq 40$ years, black race, Latino ethnicity. Assis T. (2005) found in his study that the non-white race, pre-eclampsia anterior, age over 30 years and chronic arterial hypertension were maternal risk factors associated with hypertensive disorders. In our study it was possible to determine that the mestizos were the ethnic group that mostly presented hypertensive disorders, although our cut-off points in the variable age were a little lower. Our results are related to those shown by Bigelow CA and Assis T., taking into account the predisposition according to ethnicity and age over 30 years.

Gonzáles G. (2013) found in their study that among the different factors associated with hypertensive disorders in Colombian women, the absence of prenatal check-ups (11.8\%), multiparity (56.9\%) were the main ones. Essam A. (2011), however, found that primigraves, intergenic interval $<3$ years, among others, as risk factors for pre-eclampsia, and low birth weight as a consequence of this disorder in pregnancy. In the present study it was determined that the pregnant women who had less than 5 controls were those who were more predisposed to present some type of disorder, however, at parity level our study showed that pregnant women with only one previous pregnancy and primigrams are the who mostly had disorders, regarding the level of prenatal checks agree with those of Gonzales and highlight the importance of the number of controls needed to prevent complications in pregnancy. 
Ticona M. (2012) found in her study that absence or inadequate prenatal control, illiteracy or primary education were factors related to low birth weight. In our study it was possible to determine that the newborns presented in their majority the conditions of weight and size according to their gestational stage; similarly, it was found that the majority of pregnant women who had some disorder had secondary education. Our results differ from those previously presented, possibly because pregnant women are concerned about having an adequate diet, which means that the newborn has its weight and adequate size. In addition, most of those who are older than 30 have already finished secondary school.

Cabeza A. (2014) determined in his study that age $\leq 20$ years, primiparity and arterial hypertension if they turned out to be risk factors associated with the development of pre-eclampsia. In our study we found that primiparity and hypertension as factors associated with the development of hypertensive disorders mainly pre-eclampsia. Our results agree with those of Head at the level of primiparity and present hypertension, however, they differ at the level of age, taking into account that the pregnant population is concentrated most of today in obtaining academic achievements to differences of having a child, which makes her decision to be a mother at an advanced age.

\section{Conclusions}

In this investigation the following conclusions were obtained: The majority of cases of hypertensive disorders occurred in patients of older ages (> 37), reaching 79\%, contradicting the world literature that indicates that pre-eclampsia develops with greater incidence in women under 25 years of age. Controls in primigravid pregnant women are essential in the presence of hypertensive disorders.

Mestizo ethnicity predominates in pregnant women with hypertensive disorders in almost $90 \%$ of the cases. When the ethnic group to which the pregnant women belonged within the studied sample was determined, it was possible to determine that the mestizas predominate within the population, it was not observed the presence of white ethnicity within the group studied.

Prenatal control is very important, especially the one that determines the evolution curve of blood pressure, assessing it with special interest in the last quarter where the disease can occur more frequently Hypertension is the main maternal history in pregnant women with hypertensive disorders in the studied population, followed by diabetes.

Almost $90 \%$ finished their pregnancy in caesarean sections, of which more than $30 \%$ were preterm products, $22 \%$ small products for gestational age, complications of these newborns due to their prematurity and the mother's added pathology. $12 \%$ of neonatal depression problems, increasing the morbidity and mortality of both the fetus and the newborn.

The main maternal complication during or after delivery is normal or by cesarean section is uterine hemorrhage ( $8 \%$ ), followed by HELLP syndrome (4\%). Hypertensive disorders should be detected early to stop their evolution and avoid maternal and fetal complications. 


\section{Annexes}

Hypertensive disorders in HGOECS period 2010-2014

\begin{tabular}{|l|l|l|l|l|l|}
\hline TRASTORNO & $\mathbf{2 0 1 0}$ & $\mathbf{2 0 1 1}$ & $\mathbf{2 0 1 2}$ & $\mathbf{2 0 1 3}$ & $\mathbf{2 0 1 4}$ \\
\hline Pre-eclampsia severa & 1314 & 1518 & 1612 & 1592 & 1271 \\
\hline Pre-eclampsia moderada & 548 & 498 & 81 & 37 & 29 \\
\hline Eclampsia & 137 & 137 & 102 & 120 & 92 \\
\hline Pre-eclampsia no especificada & 41 & 20 & 18 & 34 & 30 \\
\hline Pre-eclampsia en el puerperio & 35 & 27 & 33 & 33 & 11 \\
\hline $\begin{array}{l}\text { Trastornos hipertensivos preexistentes con proteinurea } \\
\text { agregada }\end{array}$ & 19 & 11 & 29 & 16 & 13 \\
\hline TOTAL GENERAL & 2094 & 2211 & 1875 & 1832 & 1446 \\
\hline
\end{tabular}

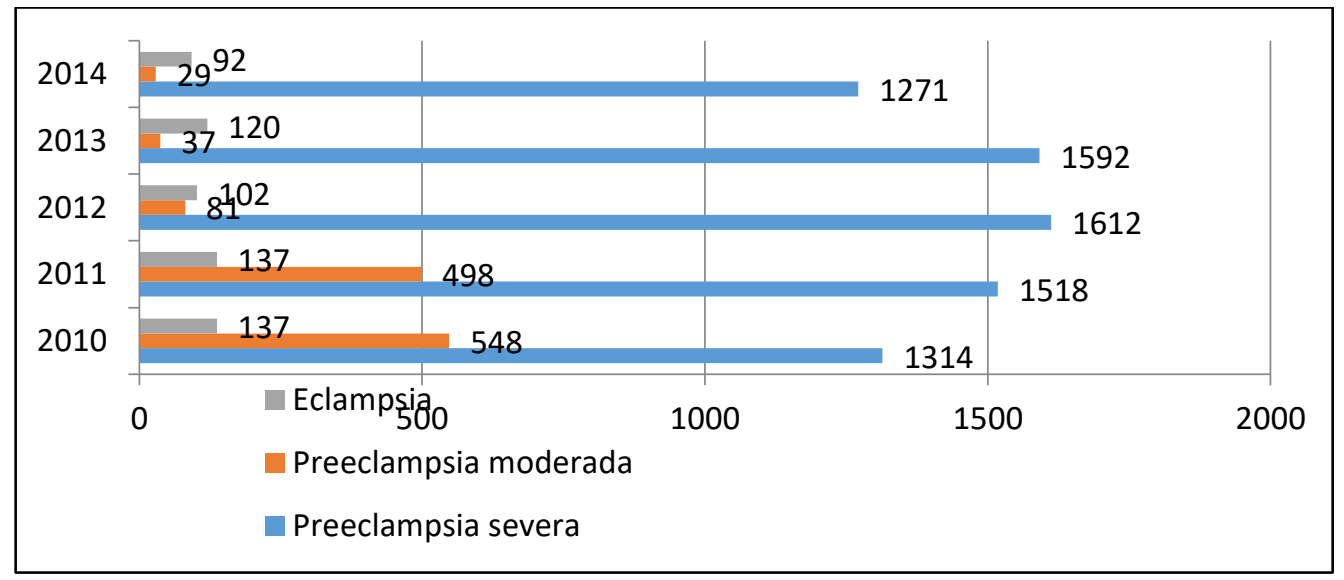

Number of cases of hypertensive disorders in HGOECS period 2010-2014

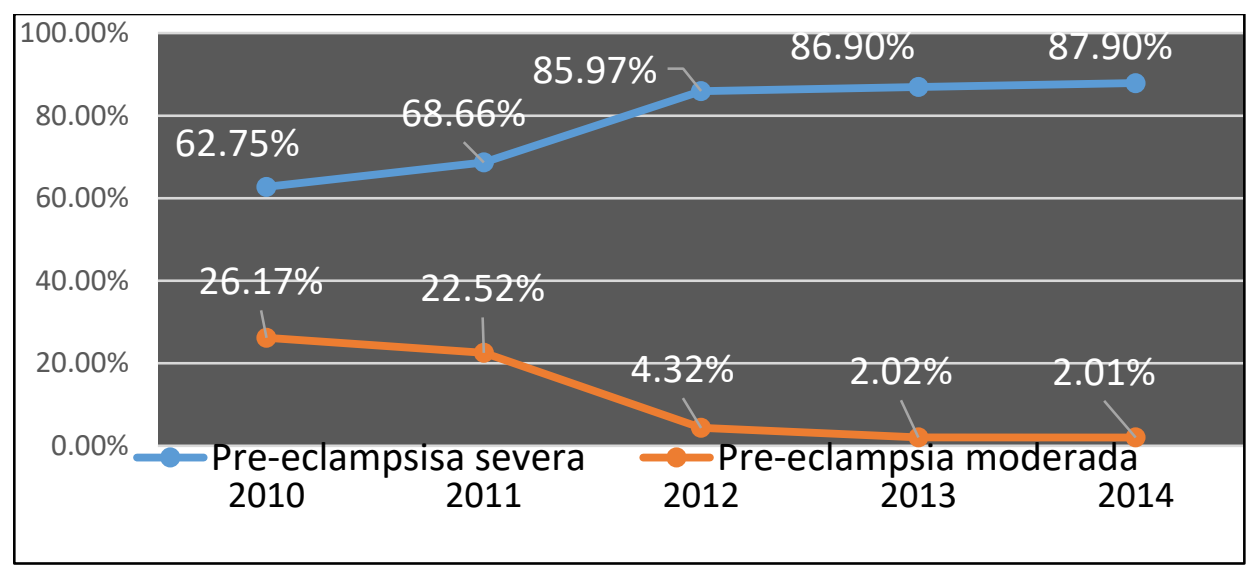

Annual increase of cases of severe and moderate pre-eclampsia in HGOECS period 2010-2014.

\section{Bibliographic References}

[1] Amarán J, Sosa M, Pérez M, et al. (2011) Principales características de la preeclampsia grave en gestantes ingresadas en un hospital de Zimbabwe 2009. MEDISAN ;13(3) BVS.

[2] Assis, Thais Rocha; Viviana, Fabiana Pavan; Rassi, Salvador. Estudio sobre los principales factores de riesgo maternos en trastornos hipertensivos del embarazo, Hospital de Clínicas de la Universidad 
Federal de Goiás, Brazil. 2005 [Artículo científico] [Accedido 26.1.16] Disponible en: http://bases.bireme.br/cgi-

bin/wxislind.exe/iah/online/?IsisScript=iah/iah.xis\&src=google \&base=LILACS\&lang=p\&nextAc tion=lnk\&exprSearch $=486803$ \&indexSearch $=$ ID

[3] Bigelow CA; Pereira GA; Warmsley A; Cohen J; Getrajdman C; Moshier E; Paris J; Bianco A; SH Factor; Piedra J. Factores de riesgo de nueva aparición tardía preeclampsia posparto en mujeres sin antecedentes de preeclampsia. Hospital Mount Sinai, Nueva York. 2014. Am J Obstet Gynecol; 210 (4): 338.e1-8 de 2014 abril. MEDLINE | ID: mdl-24211478. 2013. [Artículo científico] [Accedido: 25.1.16]. Disponible en:

http://pesquisa.bvsalud.org/portal/resource/pt/mdl-23973398.

[4] Bonilla. (2008). Obstetricia, reproducción y ginecología básicas.

[5] Briones Garduño, D. J. (2010). Cirugia medica de mexico.preeclampsia.

[6] Cabeza Acha Javier Antonio. Factores de riesgo para el desarrollo de preeclampsia atendidas en el Hospital de Apoyo Sullana. Perú. 2013. [Tesis Titulo Medico cirujano].

[7] Chan, \& Gerscovic, e. (2005). Imaging of subcapsular hepatic and renal hematomas in pregnacy complicated by preeclampsia and the hellp sydrome.j chin ultrasound.

[8] Gant, F. (2010). Norman hipertension en el embarazo. 1 Edición . México.

[9] Johson, D. (2007). Norman hipertensión en el embarazo. 1 Edición.

[10] LORQUET, S. (Abril de 2010). Acta Clin Belg. A etiology and physiopathology of preeclampsia and related forms, 237-41.

[11] medicablogs.diariomedico. (s.f.). Obtenido de http://medicablogs.diariomedico.com/frankatacho/2009/12/03/la-preeclampsia-su- epidemiologiay-teorias/

[12] Reece. (s.f.). Hobbins Obstetricia Clinica (3era Edición ed.). Editorial Medica Panamericana.

[13] Romen, D. J. (2012). Preeclampsia enfermedades hipertensivas del embarazo.

\section{Bibliografia}

[1] Amarán J, Sosa M, Pérez M, et al. (2011) Principales características de la preeclampsia grave en gestantes ingresadas en un hospital de Zimbabwe 2009. MEDISAN ;13(3) BVS.

[2] Assis, Thais Rocha; Viviana, Fabiana Pavan; Rassi, Salvador. Estudio sobre los principales factores de riesgo maternos en trastornos hipertensivos del embarazo, Hospital de Clínicas de la Universidad Federal de Goiás, Brazil. 2005 [Artículo científico] [Accedido 26.1.16] Disponible en: http://bases.bireme.br/cgi-

bin/wxislind.exe/iah/online/?IsisScript=iah/iah.xis\&src=google\&base=LILACS\&lang=p\&nextAc tion $=\operatorname{lnk} \&$ exprSearch $=486803$ \&indexSearch $=$ ID

[3] Beals, E., Caceda, L., Carvajal M., A., Saravia, A., \& Olivares, C. (2009). Estudio comparativo de morbimortalidad del producto gestacional en mujeres embarazadas conpreeclampsia moderada $\mathrm{o}$ severa. Anacem, Vol. 3(ISSN 0718-5308).

[4] Bilano VL; E Ota; Ganchimeg T; Mori R; Souza JP. Los factores de riesgo de la preeclampsia / eclampsia y sus resultados adversos en los países de bajos y medianos ingresos: un análisis secundario de la Organización Mundial de Salud (OMS). Tokyo-Japón. 2014. [Artículo científico]. [Accedido el 0102.16]. Disponible en: http://pesquisa.bvsalud.org/portal/resource/pt/mdl-24657964.

[5] Bigelow CA; Pereira GA; Warmsley A; Cohen J; Getrajdman C; Moshier E; Paris J; Bianco A; SH Factor; Piedra J. Factores de riesgo de nueva aparición tardía preeclampsia posparto en mujeres sin antecedentes de preeclampsia. Hospital Mount Sinai, Nueva York. 2014. Am J Obstet Gynecol; 210 (4): 338.e1-8 de 2014 abril. MEDLINE | ID: mdl-24211478. 2013. [Artículo científico] [Accedido: 25.1.16]. Disponible en: http://pesquisa.bvsalud.org/portal/resource/pt/mdl-23973398. 
[6] Bonilla. (2008). Obstetricia, reproducción y ginecología básicas.

[7] Briones Garduño, D. J. (2010). Cirugia medica de mexico.preeclampsia.

[8] Cabeza Acha Javier Antonio. Factores de riesgo para el desarrollo de preeclampsia atendidas en el Hospital de Apoyo Sullana. Perú. 2013. [Tesis Titulo Medico cirujano].

[9] Cernadas, C. (2009). Neonatologia práctica 4. Editorial Medica Panamericana.

[10] Chan, \& Gerscovic, e. (2005). Imaging of subcapsular hepatic and renal hematomas in pregnacy complicated by preeclampsia and the hellp sydrome.j chin ultrasound.

[11] CHEDRAUI, P. (May de 2014). Polymorphisms of the methylenetetrahydrofolate reductase gene (C677T and A1298C) in nulliparous women complicated with preeclampsia. Gynecol Endocrinol., $30(5): 392-6$.

[12] CHINGA, J. (2012). Tesis de grado. Preeclampsia en mujeres embarazadas atendidas en el área de Gineco-Obstetricia del Hospital Provincial Verdi Cevallos Balda desde Noviembre 2010 a Mayo 2011, 51-69. Red de biblioteca UTM.

[13] Crosby, \& Preston, R. (2009). Obstetricial anaesthesia for a parturient with preeclampsia, hellp syndrome and acute cortical blindness.can, $\mathrm{j}$ anaesth.

[14] Cruz Hernández, J., Garcia, H., Yanes Quesada, P. M., \& Isla Valdez, A. (Oct-Enero de 2008). Preeclampsia: enfoque inmunoendocrino parte 1. Revista cubana de medicina general integral version on-line (ISSN 1561-3038).

[15] Duley, L., \& Meher, S. (2008). Management of preeclampsia.

[16] Enciclopedia médica en español. (s.f.). Preeclampsia raises risk of epilepsy in offspring.

[17] Essam A. El Moselhy; Hamed O. Khalifa1; Soliman M. Amer1, Khadra Mohammad I. y M. Hani Abd. Factores de riesgo y los impactos de la preeclampsia: Estudio epidemiológico entre embarazada en El Cairo, Egipto. 2011. [Artículo científico]. Journal of American Science 2011; 7 (5): 311-323]. (ISSN: 1545 a 1003). [Artículo científico] [Accedido 20.1.16] Disponible en: http://www.americanscience.org.

[18] Faneite, P. (28 al 30 de Marzo de 2009). Taller Latinoamericano: una alianza para enfrentar los desafíos, reducir la morbilidad y mortalidad materna y perinatal. Revista Obstétrica Ginecológica Venezuela, 64 (4): 223 - 225.

[19] Faneite, P., Rojas, L., \& Briceño, G. (2006). Mortalidad materna. Análisis, 10: 26-28. SALUS.

[20] Gant, F. (2010). Norman hipertension en el embarazo. 1 Edición. México.

[21] Gonzales G. Factores de riesgo de los trastornos hipertensivos inducidos por el embarazo en mujeres atendidas en una entidad de salud de Santa Marta. Colombia. 2013. [Artículo científico]

[22] HES. (2015). Protocolos de la Junta de Beneficencia de Guayaquil en el HOSPITAL GINECOOBSTÉTRICO "ENRIQUE CARLOS SOTOMAYOR".

[23] HGOECS. (2014). Informe del departamento de estadística. Guayaquil.

[24] INEC. (2010). Población total y tasas brutas de natalidad, mortalidad general, mortalidad, infantil y materna, según regiones y provincias de residencia habitual. Obtenido de www.inec.gob.ec

[25] Johson, D. (2007). Norman hipertensión en el embarazo. 1 Edición.

[26] Ki-moon, B. (2009). Objetivos de desarrollo del Milenio - ODM. Obtenido de Informe: www.undp.org/spanish/mdg/

[27] Kickbusch, I. (2004). La nueva agenda de la salud. Perspectivas de Salud. Organización Panamericana de la Salud. Volumen 9, Número 2. Obtenido de http://www.paho.org/Spanish/DD/P

[28] La iniciativa por una maternidad sin riesgos. Safe motherhood organization. (s.f.). Obtenido de www.safemotherhood.org

[29] LORQUET, S. (Abril de 2010). Acta Clin Belg. A etiology and physiopathology of preeclampsia and related forms, 237-41.

[30] Maine, D., \& Rosenfiel, A. (2002). The AMDD program: history, focus and structure. Internat J Obstet Gynecol, 74: 99-103.

[31] Magel Valdés Yong, Jónathan Hernández Núñez. Factores de riesgo para preeclampsia. Hospital Militar Central "Dr. Luis Díaz Soto". La Habana, Cuba. 2014 [Artículo científico]. [Accedido: 18.01.16]. Disponible en: http://bvs.sld.cu/revistas/mil/vol43_3_14/mil05314.htm. 
[32] MARTIN, J. (Octubre de 2003). Births: final data for 2002. National Vital Statistics Reports, 1113.

[33] medicablogs.diariomedico. (s.f.). Obtenido de http://medicablogs.diariomedico.com/frankatacho/2009/12/03/la-preeclampsia-su- epidemiologiay-teorias/

[34] MONK, D. (Mayo de 2004). Intrauterine growth restriction-genetic causes and consequences. Seminars In Fetal \& Neonatal Medicine 9, 371-8.

[35] Mortalidad Materna (30 de agosto 2014). El Telegrafo. Recuperado de https://www.Telegrafo.com

[36] Mortalidad materna, un problema por resolver. (2009). Revista Cubana de Obstetricia y Ginecología, v.35 n.3.

[37] MSP. (2008). Componente Normativo Obstétrico Neonatal.

[38] MSP. (2013). Norma del subsistema de referencia, derivación contrareferencia, referencia inversa y transferencia del sistema nacional de salud.

[39] Perellon, J. (2009). Reducir la Mortalidad Materna. Obtenido de http://alainet.org/active/35064

[40] Preocupan cifras de mortalidad materna (abril 2015). El Tiempo. Recuperado de https://www.El Mundo.com

[41] Reece. (s.f.). Hobbins Obstetricia Clinica (3era Edición ed.). Editorial Medica Panamericana.

[42] ROBERTS, J. (Marzo de 2003). Hypertension 41. NHLBI Working Group on Research on Hypertension During Pregnancy, 437-445.

[43] Romen, D. J. (2012). Preeclampsia enfermedades hipertensivas del embarazo .

[44] Saftlas, a., Olson, D., \& Frank, A. (2002). Epidemiology of preeclampsia and eclampsia in the united states 1999-2002.

[45] The management of severe preeclampsia (Edition 8 ed.). (2009). Royal college of obstetricians an gynecologist.

[46] Ticona M. Incidencia y factores de riesgo de bajo peso al nacer en población atendida en hospitales del Ministerio de Salud del Perú.2012. [Artículo científico].

[47] Tratado de ginecología obstetricia y medicina del la producción de estados hipertensivos del embarazo: Tomo 1. (2011).

[48] Valdez, D. H. (2012). Pre eclampsia severa.

[49] Vargas H, Víctor Manuel, Acosta A, Gustavo, \& Moreno E, Mario Adán. (2012). La preeclampsia un problema de salud pública mundial. Revista chilena de obstetricia y ginecología, 77(6), 471476. https://dx.doi.org/10.4067/S0717-75262012000600013

[50] VILLAR, K. (2003). Eclampsia and pre-eclampsia: a health problem for 2000 years, 189-207. London, United Kingdom: RCOG Press.

[51] World Health Organization (2005). Mortalidad Materna. Recuperado de http://www.who.int/maternal_child_adolescent/topics/maternal/maternal_perinatal/es/

[52] Zapata, L. (2012). Taller Pre-Congreso sobre Derechos Sexuales y Reproductivos. Rev Obstet Ginecol Venez, 62 (4): 292-293.

[53] Zhang, J. (Julio de 2007). Paediatr Perinat Epidemiol. Partner change, birth interval and risk of preeclampsia: a paradoxical triangle.

[54] Zuspanfp. (s.f.). Nuevos conceptos en el conocimiento de las enfermedades hipertensivas durante el embarazo. Panorama actual.

*Corresponding author.

E-mail address: jorge.dahern@ ug.edu.ec/ alida.vallejol@ug.edu.ec/ ositos_3@yahoo.es 